\title{
Analysis of the reproductive seasonality of sheep production units in Singuilucan, Hidalgo, Mexico
}

\author{
Barrón-González, José Eduardo ${ }^{1}$; Salinas-Martínez, Jesús Armando ${ }^{1}$; Peralta-Ortiz Jesús German; \\ Olave-Leyva José Ignacio; González-Avalos, José y Avila-Castillo, Blas Rogelio
}

1 Universidad Autónoma del Estado de Hidalgo, Área Académica de Medicina Veterinaria y Zootecnia, Instituto de Ciencias Agropecuarias, Rancho Universitario, Av. Universidad, Km 1, ExHda. De Aquetzalpa, AP 32, Tulancingo, Hidalgo, México.

2 Universidad Autónoma del Estado de Hidalgo, Programa Educativo de Ingeniería en Manejo de Recursos Forestales, Instituto de Ciencias Agropecuarias, Instituto de Ciencias Agropecuarias, Rancho Universitario, Av. Universidad, Km 1, ExHda. De Aquetzalpa, AP 32, Tulancingo, Hidalgo, México.

* Correspondence: blas_avila8753@aueh.edu.mx

Citation: Barrón-González, J. E., Salinas-Martínez, J. A., Peralta-Ortiz, J. G., Olave-Leyva, J. I., GonzálezAvalos, J. \& Avila-Castillo, B. R. (2022). Analysis of the reproductive seasonality of sheep production units in Singuilucan, Hidalgo, Mexico. Agro Productividad. https://doi.org/10.32854/ agrop.v15i15.2033

Editor in Chief: Dr. Jorge Cadena Iñiguez

Received: May 14, 2021.

Accepted: January 2, 2021.

Published on-line: January, 2022.

This work is licensed under a

Creative Commons Attribution-NonCommercial 4.0 International license.

\section{ABSTRACT}

Objective: To analyze the occurrence of the reproductive seasonality and its relation to the time of the year, feeding, race, and social environment of sheep in the municipality of Singuilucan, Hidalgo, Mexico.

Design/methodology/approach: Forty-one surveys with sheep breeders were carried out. The data obtained was subject to a logistic regression analysis, in order to analyze the degree to which the said variables intervene on the occurrence or absence of seasonal anestrus periods in ewes. The environment in which they are developed and the traditional handling of production units must be taken into account.

Results: Seasonal anestrus periods have been recorded in $95.1 \%$ of the production units; such variables as seasons of the year, feeding type, race, and social environment have a significant influence $(\mathrm{P}<0.05)$. Spring is the most influential season of the year with regard to the occurrence of anestrus periods $(\mathrm{P}<0.05)$. The reproductive season reaches its peak in late spring and in summer; ewes give birth in late autumn and in winter. Study limitations/implications: Reproductive seasonality limits sheep production systems.

Findings/conclusions: Estrus take place in late spring and early summer. The season of the year, feeding type, race, and social environment are variables that influence the occurrence of seasonal anestrus in spring.

Key words: estrus occurrence, seasonal anestrus, semi-structured interviews. 


\section{INTRODUCTION}

Reproductive handling is one of the most important aspects of sheep production systems. However, this species' reproductive seasonality poses a serious hindrance: there is a clear seasonality in the reproductive activity of sheep located in temperate regions. This seasonality is regulated by the variation in the length of days throughout the year (González et al., 2014).

Reproductive seasonality is defined as a natural selection process included in the adaptation mechanisms; sheep and other species have developed endogenous rhythms that allow them to have reproductive and anestrus periods throughout the year. Yearly variations in the length of days result in an endocrine cue; the nocturnal secretion of melatonin (a hormone produced by the pineal gland) acts as a powerful seasonal synchronizer of the reproductive activity. The reproductive seasonality guarantees that births take place when food is available and the environmental temperature is appropriate for lambs (Gutiérrez, et al., 2011; Henningsen et al., 2016).

There is currently no full certainty about all the variables involved and to which degree they are able to explain, condition, or determine the occurrence of seasonal anestrus periods in ewes; however, several authors mention and emphasize that social signals within herds, race, and nutritional conditions are the most important variables and that they have a great impact on the herd's reproductive behavior and consequently its reproductive level (Wade and Jones, 2004; Arroyo, 2011).

Researches about seasonality in ewes in central Mexico have been carried out under controlled environments, with precise measurements, and they have been aimed only at the analysis of seasonality per photoperiod; however, they exclude nutritional and social factors (among others) which can influence reproductive behavior (Rosa and Bryant, 2003).

Therefore, the aim of this research was to analyze the reproductive seasonality and its relation with the season of the year, feeding type, race, and social environments in the sheep production systems of Singuilucan, Hidalgo, Mexico. Hidalgo stands out as second place in the national sheep meat production: 6,736 tons out of the 64,758 tons that are produced in the whole country (INFOSIAP, 2021). Production must be increased in order to satisfy the demand; currently, Mexico imports 6,734 tons of sheep meat (SIAP, 2020).

\section{MATERIALS AND METHODS}

The study was carried out in the municipality of Singuilucan, Hidalgo $\left(20^{\circ} 13^{\prime}\right.$ and $19^{\circ}$ $87^{\prime} \mathrm{N}$ and $98^{\circ} 36^{\prime}$ and $98^{\circ} 62^{\prime} \mathrm{W}$ ). The average altitude is 2,645.88 masl. The weather is temperate and subhumid, with an average annual temperature ranging from 12 to 18 ${ }^{\circ} \mathrm{C}$. During the driest month, rainfall falls below $40 \mathrm{~mm}$. One-hundred ninety-one sheep producers are registered in Singuilucan (INEGI, 2010).

Data was gathered and analyzed using a combination of qualitative and quantitative research methods (Schalock et al., 2000). Data was obtained from primary sources: sheep breeders, as well as their relatives and employees, were subject to semi-structured interviews, which included some specific questions.

A simple random sampling for small populations was used to obtain the interviews (Bustamante, 2011). The sample size was established through the sample size for proportion 
statistical method, taking into consideration a finite population, a $Z \alpha=1.96$ coefficient, and a $6 \%$ accuracy (Torres, 2006).

This research included a pilot study suggested by Daniel (2002) and Torres (2006) to provide a real value for $(\mathrm{p})$. Twenty surveys were applied to sheep breeders from the municipality of Singuilucan who were randomly chosen. The purpose of this study was to determine the existence of seasonal anestrus periods in their sheep herds: $95 \%$ positive answers indicate a $5 \%$ probability of error (negative answers), which was the value allocated to (p) using the rule of three. Finally, a sample size of $n=40$ sheep production units was established in order to survey 191 registered units $(\mathrm{N})$. However, in total, 41 surveys were carried out.

\section{Determining and analyzing the reproductive period}

The reproductive and birth period data reported by the breeders were statistically analyzed per seasons of the year, using the Kruskal-Wallis test included in the IBM SPSS Statistics software (López, 2013).

\section{Obtaining and analyzing the seasonal anestrus}

The seasonal anestrus period was obtained dividing the period without reproductive activity per type of natural anestrus, based on the months in which births and estrus periods are recorded for the herds. A 5-month gestational anestrus period (ewe gestation) and a 3-month lactational anestrus were taken into account. The latter period was obtained from the answers provided by the breeders regarding the age at which lambs are weaned (90 days), which is similar to the sheep's lactation (75-80 days) (Partida et al., 2013).

Therefore, seasonal anestrus was classified as a dependent variable, while the seasons of the year, feeding type, race, and the sheep's social environment were classified as independent variables. The IBM SPSS Statistics software for research methodologies (López and Fanchelli, 2015) was used to analyze the abovementioned variables, subjecting them to bivariate and multivariate logistic regressions: the significance's percentage value was obtained by R-squared.

\section{RESULTS AND DISGUSSION}

\section{Occurrence of the reproductive period}

Based on the 41 production units, the estrus takes place in late spring and early summer and births take place in late autumn and early winter $(\mathrm{P}<0.05$; Table 1$)$.

\section{Occurrence of the seasonal anestrus}

Thirty-nine production units $(95.1 \%)$ reported seasonal anestrus periods, while two production units $(4.8 \%)$ reported reproductive activity throughout the year (Table 2). Out of the two production units where animals were provided concentrated animal feeding, one had hair sheep without seasonal anestrus and other had wool sheep with seasonal anestrus.

In temperate regions, there is a close relationship throughout the year with the variation in the daylight hours of each season (Urviola and Riveros, 2017; Juárez et 
Table 1. Sheep reproductive activity reported by sheep breeders from Sunguilucan, Hidalgo, México.

\begin{tabular}{|c|c|c|c|c|}
\hline \multirow{2}{*}{$\begin{array}{l}\text { Months of } \\
\text { the year }\end{array}$} & \multicolumn{2}{|c|}{ Estrus } & \multicolumn{2}{|c|}{ Births } \\
\hline & $\begin{array}{l}\text { By month of } \\
\text { the year }\end{array}$ & $\begin{array}{c}\text { By season of } \\
\text { the year }\end{array}$ & $\begin{array}{l}\text { By month of } \\
\text { the year }\end{array}$ & $\begin{array}{c}\text { By season of } \\
\text { the year }\end{array}$ \\
\hline January & 4.88 & \multirow{3}{*}{ Winter $^{\mathrm{a}}$} & 63.41 & \multirow{3}{*}{ Winter $^{\mathrm{a}}$} \\
\hline February & 4.88 & & 36.59 & \\
\hline March & 7.32 & & 19.51 & \\
\hline April & 9.76 & \multirow{3}{*}{ Spring $^{\mathrm{b}}$} & 4.88 & \multirow{3}{*}{ Spring $^{\mathrm{b}}$} \\
\hline May & 19.51 & & 4.88 & \\
\hline June & 80.49 & & 2.44 & \\
\hline July & 78.05 & \multirow{3}{*}{ Summer ${ }^{b}$} & 2.44 & \multirow{3}{*}{ Summer ${ }^{b}$} \\
\hline August & 36.59 & & 2.44 & \\
\hline September & 17.07 & & 2.44 & \\
\hline October & 7.32 & \multirow{3}{*}{ Fall $^{\mathrm{a}}$} & 7.32 & \multirow{3}{*}{ Fall $^{\mathrm{a}}$} \\
\hline November & 4.88 & & 48.78 & \\
\hline December & 4.88 & & 90.24 & \\
\hline
\end{tabular}

${ }^{\mathrm{ab}}$ Different letters in the same column indicate a difference $(\mathrm{P}<0.05)$.

Table 2. Bivariate logistic regression analysis of the influence of the study variables on the occurrence of seasonal anestrus.

\begin{tabular}{l|c|c}
\hline \multicolumn{1}{c|}{ Variable } & $\begin{array}{c}\text { Production units per } \\
\text { variable }\end{array}$ & $\begin{array}{c}\text { Production units with } \\
\text { seasonal anestrum }\end{array}$ \\
\hline Season* & 41 & $39^{\mathrm{a}}$ \\
\hline Spring (April-June) ** & 37 & $37^{\mathrm{a}}$ \\
\hline Summer (July-September) ** & 2 & 2 \\
\hline Feeding type * & 41 & $39^{\mathrm{a}}$ \\
\hline Grazing feed ** & 33 & $33^{\mathrm{a}}$ \\
\hline Concentrated animal feeding ** & 2 & $1^{\mathrm{a}}$ \\
\hline Mixed feeding ** & 6 & $39^{\mathrm{a}}$ \\
\hline Race type** & 41 & $39^{\mathrm{a}}$ \\
\hline Wool sheep & 2 & $0^{\mathrm{a}}$ \\
\hline Hair sheep & 41 & $39^{\mathrm{a}}$ \\
\hline Sheep's social environment** & 31 & $31^{\mathrm{a}}$ \\
\hline Herds in the presence of males & 10 & $8^{\mathrm{a}}$ \\
\hline Herds in the absence of males & & \\
\hline * independent polytomous variables; ** independent dichotomous variables. \\
a The letter above the number of production units with seasonal anestrus in relation with its \\
number of production units per variable indicates a difference $(\mathrm{P}<0.05)$.
\end{tabular}

al., 2018). In wool sheep, the reproductive activity period takes place in autumn and early winter, without ovarian activity in spring and summer. However, anestrus periods have not been defined, since there are no reports about the influence of social factors (e.g., the presence of males or lactation periods). In this sense, the results of this study 
show a close relationship $(\mathrm{P}<0.05)$ : seasonal anestrus periods take place from April to June (spring) and most births take place from December to January (autumn-winter). Therefore, reproductive activity (estrus) occurs during the summer (July, August, and September). The difference between the occurrence of the estrus (peak reported in June) and the moment when the ewes gave birth (peak reported in December) recorded in this study might be explained by a low fertility percentage when the ovarian activity was renewed after the anestrus. Martin et al. (1986) mention that this behavior is mainly affected by such social factors as the incorporation of an active male. They also mention that anovulatory prepubertal, seasonal, or lactating ewes can start to leave the anestrus when they are in contact with males; physiologically, this means that LH pulses and ovulation begin to increase. Subsequently, new follicular development waves appear; a short and infertile estrus cycle usually takes place. A new normal estrus cycle then takes place, 17 to 30 days after the females have contact with the male.

Arroyo et al. (2007) and Macías et al. (2015) carried out studies in central Mexico and found out that the race of the animals has a great influence on the occurrence of seasonal anestrus. They determined that the native wool or mixed-race livestock — crossed with black-faced British races, such as Suffolk and Hampshire- has a marked seasonality, unlike hair races — such as Katahdin and Dorper which were included in two of this study's production units-, which are bred all year long (González et al. (2014).

Similarly to the findings of Partida et al. (2013) and Vázquez et al. (2018), three sheep production system types were identified in Singuilucan, Hidalgo: grazing feed, concentrated animal feeding, and mixed. Likewise, the feeding type is directly related to the production system; therefore, under the grazing feed system used in their production units, the ewes had a seasonal anestrus. In this sense, Arroyo (2011) mentions that this situation is closely related to food availability in certain moments of the year, which guarantees a higher birth survival rate among lambs. However, Arroyo et al. (2009) and González et al. (2014) mention that lambing periods for wool ewes take place in springtime, when the rain leads to new sprouts of the native grasses which this livestock eats under grazing feed systems. This study establishes that the lambing period took place in late autumn and winter (November, December, January, and February), when the weather is cold; the seasonal frost (heladas) diminishes food availability on dry season pasturelands (agostaderos), from December to February, and even March, until the rains begin in May (INAFED, 2010). However, in the Singuilucan region, cereals (e.g., maize and barley) are usually harvested during this season; however, during the last years, some producers have taken a risk growing oats and wheat. Sheep herd graze on the residues of the harvest (both fodder and grain) that can be found in the plots. The food availability required during the sheep's lactation period could explain the births that take place during this season (Inforural, 2020).

On their part, both concentrated animal feeding production system units did not have seasonal anestrus; one had hair sheep and the other had wool sheep. Therefore, in this case, both variables can be said to have been altered by the race variable. There was no relation between variables in the mixed production system.

Another study variable was the social environment; it is closely related to the occurrence of seasonal anestrus periods, both in the presence and the absence of a male. These 
results match the findings of Delgadillo et al. (2008) who mention that male-female social communication modifies the ewe's reproductive cycle, as a result of the male's effect on the ewes' reproductive system (pheromones).

On general terms, the reproductive seasonality of sheep in Singuilucan, Hidalgo, is not only determined by the photoperiod - as has been previously reported - , but also by other closely-related variables. In this sense, photoperiods are known to be responsible for the synchronization of the ewe's reproductive period, but not for the generation of a circannual reproductive rhythm and there is even an endogenous physiological rhythm in the absence of light stimuli (Rosa and Bryant, 2003). However, further research is required in this area.

\section{CONGLUSIONS}

In the handling conditions that are typical of the sheep herds in the study region, estrus takes place in late spring and early summer. Variables such as season of the year, feeding type, race, and social environment have a significant influence on the occurrence of the seasonal anestrus during the spring.

\section{AGKNOWLEDGEMENTS}

The authors would like to thank all the students and alumni of the Área Académica de Medicina Veterinaria y Zootecnia of the Instituto de Ciencias Agropecuarias - UAEH, as well as the sheep breeders of Singuilucan, Hidalgo, for their support for this research.

\section{REFERENGES}

Arroyo, J. (2011). Reproductive seasonality of sheep in México. Tropical and Subtropical Agroecosystems, 14, 829845.

Arroyo, L., Gallegos, J., Villa, A., Berruecos, J., Perera, G., \& Valencia, J. (2007). Reproductive activity of Pelibuey and Suffolk ewes at $19^{\circ}$ north latitude. Animal Reproduction Science, 102(1-2), 24-30. doi:10.1016/j.anireprosci.2006.09.025

Arroyo, J., Magaña, H., \& Camacho, M. (2009). Regulación neuroendocrina del anestro posparto en la oveja. Tropical and Subtropical Agroecosystems, 10(3), 301-312.

Bustamante, G. (2011). Aproximacion al muestreo estadistico en investigaciones cientificas. Revista de Actualización Clínica, 10, 476-480.

Daniel, W. (2002). Bioestadística. México: LIMUSA.

Delgadillo, J., Vielma, J., Flores, J., Véliz, F., Duarte, G., \& Hernández, H. (2008). La calidad del estímulo emitido por el macho determina la respuesta de las cabras sometidas al efecto macho. Tropical and Subtropical Agroecosystems, 9(1), 39-45.

González, A., Urrutia, J., \& Gámez, H. (2014). Comportamiento reproductivo de ovejas dorper y katahdin empadradas en primavera en el norte de México. Tropical and Subtropical Agroecosystems, 17(1), 123-127.

Gutiérrez, G., Rangel, L., \& Lassala, A. (2011). Pubertad, ciclo estral y estacionalidad. En C. Galina, \& J. Valencia, Reproduccón de los animales domesticos (págs. 85-117). México: Limusa

Henningsen, J., Gauer, F., \& Simonneaux, V. (2016). RFRP Neurons - The Doorway to Understanding Seasonal Reproduction in Mammals. Frontiers In Endocrinology, 7(36), 1-10.

INAFED. (2010). Enciclopedia de los municipios y Delegaciones de México. Recuperado el 2020, de Singuilucan: http://www.inafed.gob.mx/work/enciclopedia/EMM13hidalgo/municipios/13057a.html

INEGI. (2010). Unidad de microrregiones. Recuperado el 26 de Agosto de 2019, de SEDESOL: http://www. microrregiones.gob.mx/zap/datGenerales.aspx?entra=nacion\&ent=13\&mun=057

Inforural. (2020). Trigo y avena se siembran en Singuilucan. Recuperado el 2020, de Inforural: https://www. inforural.com.mx/trigo-y-avena-se-siembran-en-singuilucan/

Infosiap. 2021. Avance de la producción pecuaria por producto. [online] Available at: <http://infosiap.siap.gob. mx/repoAvance_siap_gb/pecAvanceProd.jsp> [Accessed 14 May 2021]. 
Juárez, A., Domínguez, A., Pinzón, L., E, A., Rivera, J., \& Ramón, J. (2018). Estacionalidad reproductiva en ovejas tropicales superovuladas. Agroproductividad, 11(10), 133-135. doi.org/10.32854/agrop. v1 lil0.1257

López, P. (2013). Contraste de hipótesis. Comparación de más de dos medias independientes mediante pruebas no paramétricas: Prueba de Kruskal-Wallis. Enfermeria del Trabajo, 3(18), 166-171.

López, P., \& Fanchelli, S. (2015). Metodología de la investigación social cuantitativa. Barcelona: UAB.

Macías, A., Sánchez, T., Gastelum, M., Avendaño, L., Correa, A., Álvarez, F., y otros. (2015). Actividad reproductiva estacional de ovejas pelibuey bajo condiciones áridas de México. Archivos de Medicina Veterinaria, 47(3), 381-386. doi:10.4067/S0301-732X2015000300016

Martin, G., Oldham, C., Cognié, Y., \& Pearce, D. (1986). The physiological responses of anovulatory ewes to the introduction of rams. Livestock Production Science, 15(3), 219-247. doi: 10.1016/0301-6226(86)90031-x

Partida de la Peña, J., Braña, D., Jiménez, H., Ríos, F., \& Buendía, G. (2013). Produccón de carne ovina. Ajuchitlán Querétaro: INIFAP.

Paul,J. (2010).Academia.edu. Recuperado el 2020, de copyleft: https://www.academia.edu/27601604/Variables_ Dependientes_e_Independienteshdh

Rosa, H., \& Bryant, M. (2003). Seasonality of reproduction in sheep. Small Ruminant Research, 48, 155-171. doi:10.1016/S0921-4488(03)00038-5

Schalock, Robert L., Gordon S. Bonhamb, Cristine B. Marchand. (2000). Consumer based quality of life assessment: a path model of perceived satisfaction. Evaluation and program planning. 23: 77-87. doi:10.1016/S0149-7189(99)00041-5

SIAP. 2020. Panorama agroalimentario 2020. [online] Available at: <https://nube.siap.gob.mx/gobmx publicaciones_siap/pag/2020/Atlas-Agroalimentario-2020> [Accessed 14 May 2021].

Torres, M. (2006). Facultad de Ingeniería - Universidad Rafael Landívar boletín electrónico . Recuperado el 11 de Diciembre de 2019, de Tamaño de una muestra para una investigación de mercado: http:// fgsalazar.net/LANDIVAR/ING-PRIMERO/boletin02/URL_02_BAS02.pdf

Urviola, A., \& Riveros, J. (2017). Factores moduladores de la estacionalidad reproductiva en ungulados. Investig. Altoandin, 19(3), 319 - 336. doi.org/10.18271/ria.2017.297

Vázquez, I., Jaramillo, L., Bustamante, A., Vargas, S., Calderón, F., Torres, G., y otros. (2018). Structure and typology of sheep production units in central México. Agricultura, sociedad y desarrollo, 15(1), 85-97.

Wade, G., \& Jones, J. (2004). Neuroendocrinology of nutritional infertility. Am J Physiol Regul Integr Comp Physiol, 287, 1277-1296. doi: 10.1152/ajpregu.00475.2004. 